\title{
実形状肺気道内振動流に発生する乱れの空間・時間的変化*
}

\author{
田中 学*1, 羽鳥 彰浩*2, 高野 了輔 ${ }^{* 3}$
}

\section{Spatial and Temporal Variation of Turbulence during Oscillatory Flow in Realistic Model Human Airways}

\author{
Gaku TANAKA ${ }^{* 1}$, Akihiro HATORI and Ryosuke TAKANO \\ ${ }^{* 1}$ Graduate School of Engineering, Chiba University, \\ 1-33 Yayoi-cho, Inage-ku, Chiba, 263-8522 Japan
}

To reveal the nature of turbulence in a lung, the measurements of turbulence in the oscillatory flow in realistic model human central airways were made by particle image velocimetry (PIV). The transparent silicon model of multi-branching airways was fabricated from X-ray $\mathrm{CT}$ images by rapid prototyping. The multi-branching airways comprise trachea, right and left bronchi and airway diameters range from 14 to $2 \mathrm{~mm}$. Experiments were performed for the Reynolds number from 1200 to 2200 and for the Womersley number from 1.9 to 2.3 in the trachea. The spatial and temporal variations of turbulent intensity were strongly dependent on the airway geometry and the phase of oscillatory flow. The expiratory flow generates strong turbulence which explosively occurs in the entire cross section especially in the right bronchi, whereas the inspiratory flow generates relatively weak turbulence near the airway wall.

Key Words : Pipe Flow, Oscillatory Flow, Turbulence, Bio-Fluid Mechanics, PIV, Airway, Respiratory System

\section{1. 緒言}

ヒトの肺気道は，3 次元的に分岐を繰り返寸複雑なネットワークで構成されている. 気道内の流れは呼気と吸 気で流れの方向が反転する往復流であり，この往復流によって酸素や二酸化炭素，またタバコの煙や各種エアロ ゾル等の微粒子が輸送されている，気道内の物質輸送は，近年ではドラッグデリバリーに関連して，微粒化薬物 の輸送経路としても注目を集めている ${ }^{(1)}$. 気管から数世代の比較的径の太い気道では，レイノルズ数及びペクレ 数が 1000 以上と見積もられ，流れや物質輸送は対流の影響に支配される ${ }^{(2)}$.このため，比較的径の太い気道内の 流れに関して，従来多くの研究報告がある.

気道内の流れの特徵に関しては, 気道の曲がりや分岐等の比較的単純な幾何学的要素を抽出したモデル流路を 用いた研究が多く報告されている。これまでに，対称または非対称分岐からなる単分岐管あるいは多分岐管内に 生じる二次流れやはく離渦の特徵が，実験及び数值計算により明らかにされている(3) (6). 平面的な分岐管ネット ワーク流路内ではパーティクルトラッキングの数值計算が行われ, 気道内のエアロゾル沈着に関して検討されて いる(7)(8). 一方, 近年では X 線 CT 等の医療画像から再構築された実形状肺気道モデルを用いた数值計算が行われ るようになっており，単純化モデルと比較した流動パターンの変化が報告されている(9) (12). しかしながら，これ ら気道内の流れに関する研究の多くは，流れの状態が層流であると仮定されている.

流れの方向の反転を伴う振動流に発生する乱れに関しては，直円管を用いた実験において，一周期の間に乱流 遷移と再層流化を繰り返寸振動流独特の乱流遷移が報告されている(13) (15). これらの研究では, 流れの減速期に 激しい速度変動を伴う Conditional Turbulenceへの遷移が，ストークス層厚さで定義したレイノルズ数で整理され

\footnotetext{
* 原稿受付 2010 年 6 月 3 日

*1 正員, 千葉大学大学院 工学研究科（广263-8522 千葉県千葉市稲毛区弥生町 1-33）

*2 千葉大学大学院 工学研究科

*3 学生員, 千葉大学大学院 工学研究科

E-mail: gtanaka@faculty.chiba-u.jp
} 
ている(13)．気道のような分岐流路に発生する乱れの研究例は少ないが，対称単分岐管を用いた振動流の可視化実 験においては，比較的低いレイノルズ数で乱流遷移と再層流化を繰り返寸直円管内の乱流に類似した流れが確認 されている(3). 著者らは，対称単分岐管内振動流の LDV 測定から，呼気・吸気で著しく異なる乱れの特徵を報告 している ${ }^{(16)}$. しかしながら, 実際の複雑な肺気道形状のもとで発生寸る乱れに関しては, ほとんど知見が得られ ていない.

このような背景のもと, 本研究では実形状肺気道内の乱れの遷移, 空間・時間的変化を明らかにすることを目 的とする. そのために, X 線 CT 医療画像データを基に作製した実形状肺気道モデル流路に振動流を与え, 乱れ の発生する流量条件，位置及び位相を PIV 計測により定量的に評価した.

\section{おもな記号}

$\begin{array}{ll}a & : \text { 気管入口半径 } \\ \operatorname{Re} & : \text { 気管入口直径で定義したレイノルズ数 }=2 U_{0} \cdot a / v \\ \operatorname{Re}_{\delta} & : \text { ストークス層厚さで定義したレイノルズ数 }=U_{0} \cdot \delta / v \\ t & : \text { 時間 } \\ T & : \text { 周期 } \\ u & : \text { 流速 } \\ <u> & : \text { アンサンブル平均流速 } \quad \text { [式 }(1)] \\ u_{\mathrm{rms}}^{\prime} & : \text { 乱れ強度 [式 }(3)] \\ U_{0} & : \text { 気管入口の管軸方向断面平均流速振幅 } \\ \alpha & : \text { ウォマスリイ数 }=a(\omega / v)^{0.5} \\ \delta & : \text { ストークス層厚さ }=(2 v / \omega)^{0.5} \\ v & : \text { 動粘性係数 } \\ \omega & : \text { 角周波数 }\end{array}$

\section{2. 実験装 置及び方法}

\section{$2 \cdot 1$ 実形状肺気道モデル}

図 1 に, 実形状肺気道モデル流路を示寸. 本研究では, CT 画像から気道断面を抽出して再構築した実肺気道 形状（図 1(a)）を用いて，1:1 スケールの透明シリコーン樹脂製流路を作製した(図 1(b)). 気道断面の抽出は，70 代男性の高さ方向に $3 \mathrm{~mm}$ 間隔で撮影された計 80 枚の CT 画像 $(0.625 \mathrm{~mm} / \mathrm{pixel})$ から, 3 次元的な領域拡張法 により行われた ${ }^{(17)}$. 実肺気道形状は, 抽出された気道断面と, 高さ方向 $1 \mathrm{~mm}$ 間隔でスプライン補間により作成

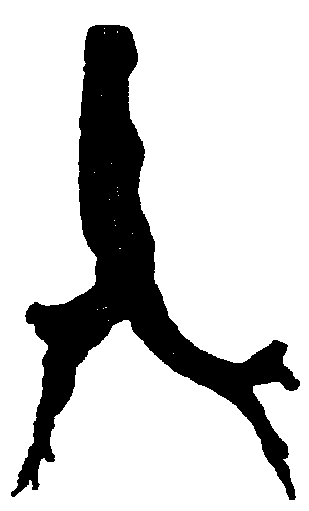

(a) CT-based airway geometry
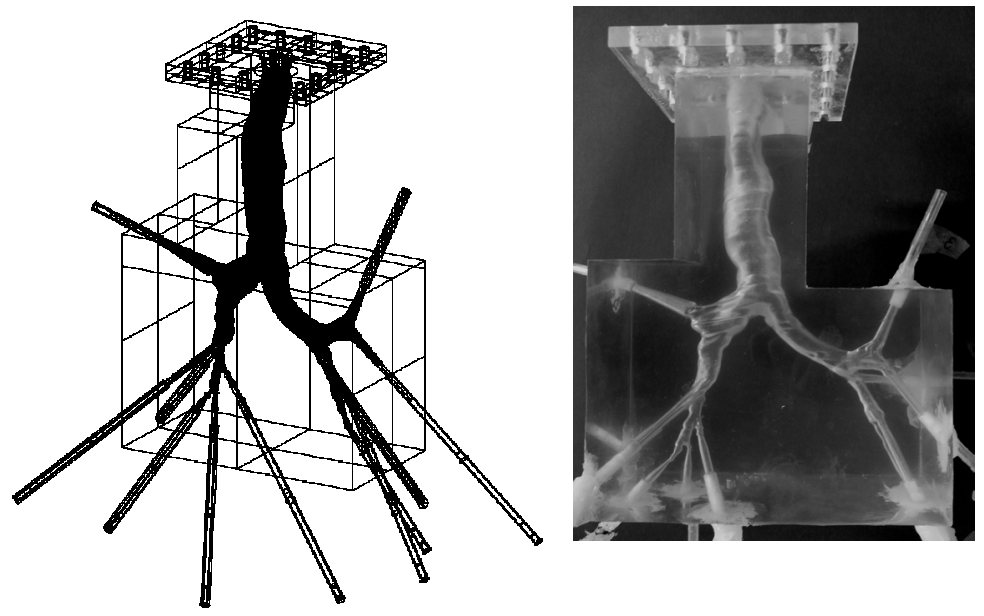

(b) Silicone flow model

Fig. 1 Airway model 
された気道断面より 3 次元画像解析ソフト（3D-DOCTOR, Ver. 3.5）を用いて再構築され，気管（径約 $15 \mathrm{~mm}$ ）か ら左右気管支を経て最大 7 世代までの気道（径約 $2 \mathrm{~mm}$ ）より構成されている．気道モデル流路においては，末 端側気道出口（11 箇所）の先に気道の軸方向にゆるやかなテーパー部が設けられ，気道径に応じて内径 $6 \mathrm{~mm} ま$ たは $4 \mathrm{~mm}$ のアクリル直円管が接続されるよう考慮されている. 透明シリコーン樹脂製流路は, 肺気道形状デー タを基に作製した光造形モデル（株式会社デンケン製）を低融点金属ロストモデルに転写することにより，ロス トモデリング法で作製された.

本モデルでは，固有の病変などの認められない気道形状が抽出されている．直円管に近い特徵を有する気管よ り，左右に異なる角度・気道径で分岐する非対称分岐管，また分岐後には様々な曲率・長さの曲がり管としての 特徵を有する気管支が連なっており，これらの管路が全体として非対称多分岐管ネットワークを構成している. 従来の気道モデルの多くは平面的な分岐で理想化されているのに対し, 実際の分岐形状は 3 次元的である. また 気道壁はなめらかな壁で理想化されているのに対し，実際には軟骨輪による凹凸構造が存在している．本研究の 実形状肺気道モデルは基本的にこれらの幾何学的要素の組み合わせとして理解される.

\section{$2 \cdot 2$ 実験装置}

図 2 に，実験装置の概略図を示す，実験装置は，振動流発生装置，リザーバ，気道モデル流路，流量分配抵抗 部, 接続チューブ及びメスシリンダーで構成されている. 作動流体は, シリコーンと屈折率の等しい体積濃度 $50 \%$ グリセリン水溶液（屈折率 1.41 , 動粘性係数 $4.69 \times 10^{-6} \mathrm{~m}^{2} / \mathrm{s}$ ）である. 振動流発生装置は, サーボモータとその 回転運動を往復運動に変換するスコッチョーク機構で構成され，ベローズを介してリザーバ $(120 \mathrm{~mm} \times 120 \mathrm{~mm}$ $\times 130 \mathrm{~mm}$ ）に接続される. 振動流の周期は 14〜20 s, 拍動体積は 340～620 ml である.リザーバ内には， ベロー ズから吐出される流れが直接気道モデル流路に流入しないよう，仕切板を設置した．リザーバと気道モデル流路 の接続部は, 流れが滑らかに流入するようにベルマウス状となっている. 未端側気道に接続された各直円管内に,

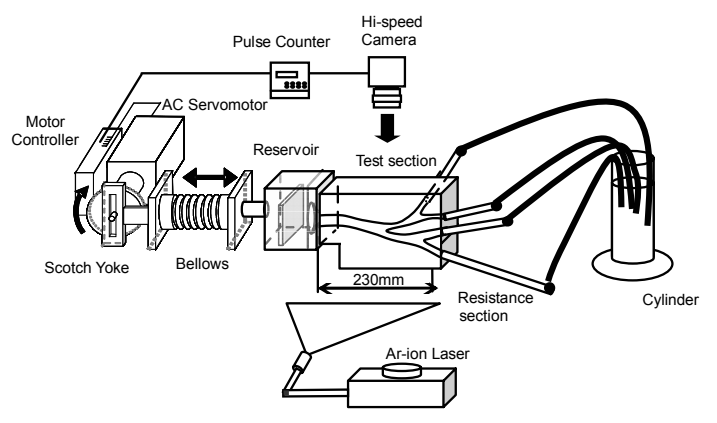

Fig. 2 Experimental apparatus

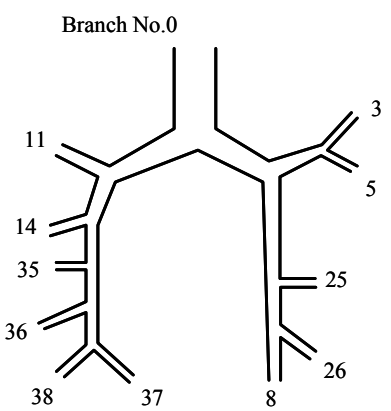

Fig. 3 Branch number reported by Horsfield et al. ${ }^{(18)}$

Table 1 Distribution of flow at $\operatorname{Re}=1700$ and $\alpha=2.1$

\begin{tabular}{|r|r|r|}
\hline Branch No. & $\begin{array}{c}\text { Horsfield model } \\
{[\% \text { of trachea] }}\end{array}$ & $\begin{array}{c}\text { Present study } \\
{[\% \text { of trachea }]}\end{array}$ \\
\hline 0 & 100 & 100 \\
\hline 3 & 14 & 19 \\
\hline 5 & 6 & 6 \\
\hline 8 & 12 & 10 \\
\hline 11 & 22 & 24 \\
\hline 14 & 10 & 6 \\
\hline 25 & 5 & 5 \\
\hline 26 & 8 & 7 \\
\hline 35 & 7 & 7 \\
\hline 36 & 4 & 5 \\
\hline 37 & 6 & 6 \\
\hline 38 & 6 & 5 \\
\hline
\end{tabular}


内径 $0.5 \mathrm{~mm}$ の細管を束ねて挿入した流路抵抗部を設けて, 各直円管への流量分配比を調節した．流路抵抗は, 流路分配比が Horsfield らの非対称肺気道モデルで報告されている分配比 ${ }^{(18)}$ と一致するよう, 細管の長さにより 調節された．各直円管は，ビニルチューブで容積 $1000 \mathrm{ml}$ のメスシリンダーに導かれる. 流量分配比の確認のた め, 各ビニルチューブを個別に少容積 $(100 \mathrm{ml})$ のメスシリンダーに導き液面振幅から流量分配比を測定した結果， Horsfield らの流量分配比とのずれは最大で $5 \%$ であった（図 3，表 1 ).

流れの可視化は, トレーサ粒子のプラスチックビーズ（三菱化学製，ダイヤイオン，比重 1.02 , 粒径 $50 \mu \mathrm{m}$ ) に，気道モデル流路側面より厚み $1 \mathrm{~mm}$ のアルゴンイオンレーザシート (KANOMAX 製, 出力 $400 \mathrm{~mW}$ ) を照射 して行われた. 可視化画像は, 流路上部（ヒトの背側）より, パルスカウンター (KEYENCE 製, KV-10AT) を 介してサーボモータと同期させた高速度カメラ (DITECT 製, HAS-220, 600 fps, 228×320 ピクセル) で撮影された.

\section{$2 \cdot 3$ 乱れの PIV 計測}

図 4 に，本実験で PIV 計測を行った 3 つ断面（A，B，C）を示寸． A 面は気管から第 1 分岐，B，C面はそ れぞれ右, 左気管支から第 2 分岐にかけての断面となっている. 各断面の画像分解能は, A 面で $0.152 \mathrm{~mm} / \mathrm{pixel}$, $\mathrm{B}$ 及び $\mathrm{C}$ 面で $0.110 \mathrm{~mm} / \mathrm{pixel}$ である. それぞれの断面で, $1 / 8$ 周期每に 2 枚づつ, 計 128 周期分の可視化画像を 撮影した．各位相における 2 枚の画像の撮影間隔は $1 / 600 \mathrm{~s}$, 撮影時のシャッタースピードは $1 / 1000 \mathrm{~s}$ である. 各 位相 2 枚の画像より, PIV 解析ソフト (nexus PIV EXPERT 2000, Ver. 1.11e) を用いて画像相互相関法により 128 周期分の瞬時速度分布図を算出した. PIV 解析における格子間隔は 6 pixel である. なお, 代表的な流れの条件 (レ イノルズ数 $\mathrm{Re}=1700$ 及びウォマスリィ数 $\alpha=2.1$, 無次元数の詳細については $2 \cdot 4$ 実験条件に記す）では, 一周期間の瞬時流速波形を算出するため, 1 周期を通して $1 / 600 \mathrm{~s}$ 間隔の連続撮影を行った.

得られた各位相 128 枚の瞬時速度分布図から, 乱れ強度を算出した。任意の位置における瞬時速度を $u_{i}(t)$ とす ると, アンサンブル平均流速は $<u(t)>$ は次式で示される.

$$
\langle u(t)\rangle=\frac{1}{N} \sum_{i=1}^{N} u_{i}(t)
$$

ここで $N$ は周期数である. 流れの変動速度 $u_{\mathrm{i}}^{\prime}(t)$ は, 瞬時流速とアンサンブル平均との差として算出される.

$$
u_{i}{ }^{\prime}(t)=u_{i}(t)-\langle u(t)\rangle
$$

乱れ強度 $u_{\mathrm{rms}}^{\prime}(t)$ は $u_{\mathrm{i}}^{\prime}(t)$ を用いて次式で定義される.

$$
u^{\prime}{ }_{r m s}(t)=\left\langle u_{i}{ }^{\prime}(t)^{2}\right\rangle^{1 / 2}
$$

本 PIV 計測手法の妥当性を検証するため, シリコーン樹脂で作成した管径 $15 \mathrm{~mm}$ の直円管で振動流の流速分 布を測定した。流れの条件は層流，発達流れである。流速分布を厳密解と比較した結果（図 5), 両者には概ね良 い一致がみられた．また，このとき算出された $u_{\mathrm{rms}}^{\prime}(t)$ は最大でも $0.04 \mathrm{~m} / \mathrm{s}$ であった.

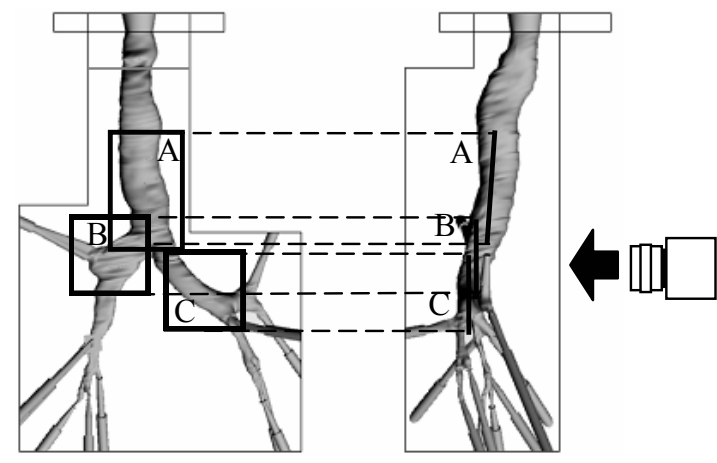

Fig. 4 Location of PIV measurement sections

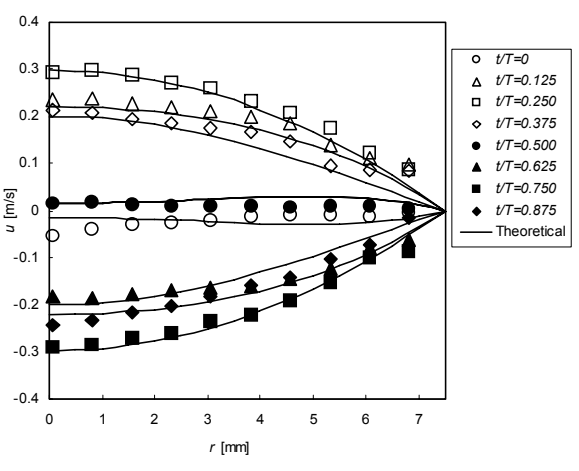

Fig. 5 Comparison between measured velocity profile and theoretical solution in a straight tube at $\mathrm{Re}=610$ and $\alpha=2.1$ 


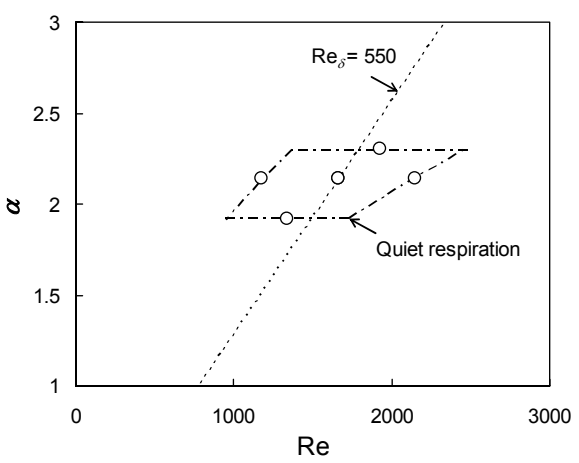

Fig. 6 Stability diagram of Re versus $\alpha$

\section{$2 \cdot 4$ 実験条件}

気道内振動流の流動条件を表す無次元パラメータとして, 以下に示すレイノルズ数 Re, ウォマスリィ数 $\alpha$ を 用いた ${ }^{(3)}$.

$$
\begin{aligned}
& \operatorname{Re}=2 a U_{0} / v \\
& \alpha=a(\omega / v)^{1 / 2}
\end{aligned}
$$

ここで， $a$ は気管入口半径 $(=7.5 \mathrm{~mm}), \omega$ は角周波数， $v$ は 動粘性係数， $U_{0}$ は気管入口軸方向断面平均流速の 振幅である．また，ストークス層厚さを代表長さとしたレイノルズ数 $\operatorname{Re}_{\delta}$ を次式で定義した.

$$
\operatorname{Re}_{\delta}=U_{0}(2 v / \omega)^{1 / 2} / v
$$

図 6 に, 本実験の流動条件をRe と $\alpha$ を用いた状態図上に示す. 振動流において $\alpha$ が増加すると, ストークス層 厚さが管半径に対して薄くなり $(\alpha>1)$, 管中央部には速度勾配のないコア領域が形成される. このような流れ 場はストークス層厚さによって特徵づけられ， $\mathrm{Re}_{\delta}$ の増大に伴い加速期は層流状態を保ったまま減速期において 高周波かつ大振幅の乱れが発生する Conditional turbulence 一と遷移する. 図中の破線は，直円管内振動流の Conditional turbulence 一の遷移条件 $\left(\mathrm{Re}_{\delta}=550\right)$ を示し ${ }^{(13)}$, 遷移条件より左側の領域は層流あるいは全位相を通じ て弱い乱れが観測される領域，右側の領域は Conditional turbulence が観測される領域に相当している．一点鎖線 の枠で囲まれた領域は，本実験で対象とした安静時呼吸に相当する条件（ $\mathrm{Re}=1200 \sim 2200$ 及び $\alpha=1.9 \sim 2.3$, 作 動流体が空気の場合は一回換気量 340 $620 \mathrm{ml}$, 周期 4.3 6.2 s に相当）を示す. 本実験では, $R e=1700$ 及び $\alpha=$ 2.1 の条件 (一回換気量 $480 \mathrm{ml}$, 周期 $5.0 \mathrm{~s}$ に相当)を基準にして一回換気量または周期を増減させることにより, 図 6 中の 5 条件で測定を行った. $\operatorname{Re}_{\delta}$ の範囲は 390 〜10である.

\section{3. 実験結果及び考察}

\section{$3 \cdot 1$ 一周期間の瞬時流速波形}

図 7 に，本実験で観測された乱れの例として，気管及び左右気管支それぞれの管中央及び管壁近傍における一 周期間の瞬時流速波形を， $\mathrm{Re}=1700 ， \alpha=2.1$ の場合（ $\mathrm{Re}_{\delta}=570 ）$ について示す.この流れの条件におけるスト 一クス層厚さは約 $5 \mathrm{~mm}$ であるのに対し, 瞬時流速波形を示した管壁近傍位置は全て壁から約 $2 \mathrm{~mm}$, 管中央位置 は気管，右気管支，左気管支でそれぞれ壁から約 $10 \mathrm{~mm}, 8 \mathrm{~mm}, 5 \mathrm{~mm}$ 離れた地点に位置している. 瞬時流速は 絶対值で示し，気管入口の管軸方向断面平均流速振幅で無次元化して表示している $\left(|u| / U_{0}\right) . t / T=0 \sim 0.5$ が吸 気位相, $t / T=0.5 \sim 1.0$ が呼気位相である. 図 7 より, 吸気と呼気のいずれの位相でも, また気管と左右気管支, 管中央と管壁のいずれの位置でも，激しい高周波の速度変動を伴う乱れが発生していることがわかる．速度変動 は，吸気・呼気とも各位置で加速期中頃 $(t / T \sim 0.1 ， 0.6 ）$ から発生しており，最大流量位相 $(t / T \sim 0.25,0.75)$

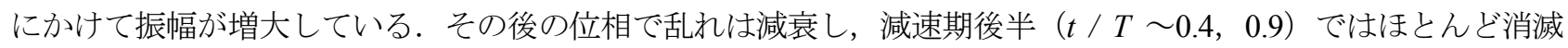



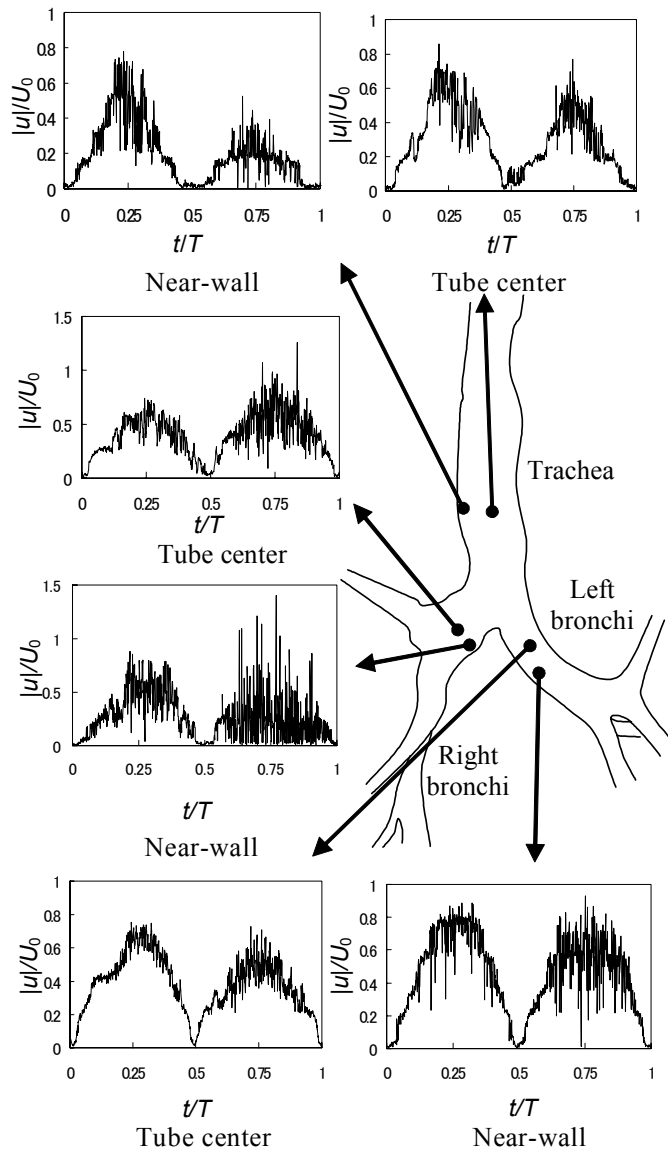

Fig. 7 Phase variation of the instantaneous velocity at $\operatorname{Re}=1700$ and $\alpha=2.1$

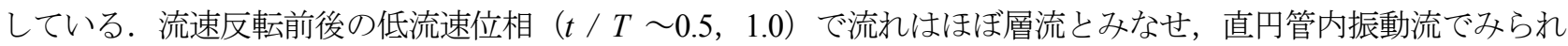
る Conditional turbulence と同様，一周期の間で乱流遷移と再層流化を繰り返していると考えられる. しかしなが ら, Conditional turbulence では減速期に高周波の速度変動を伴うのに対して, 気道モデル流路内の乱れは流れの最 大流量位相付近で観測されている．最大流量位相付近の乱れは，曲がり管内振動流 ${ }^{(19)}$, 単分岐管内振動流 ${ }^{(16)}$ にお いても報告されており，乱れの発生は曲がりや分岐によって誘起される二次流れの影響を強く受けていると考え られる。

\section{$3 \cdot 2$ 乱れ強度の空間 - 時間的変化}

図 8，9 に，それぞれ吸気位相（ $t / T=0 \sim 0.5 ）$ 及び呼気位相 $(t / T=0.5 \sim 1.0)$ の乱れ強度の空間・時間的变化 を示寸 $\left(u_{\mathrm{rms}}^{\prime} / U_{0}\right)$. 図中の矢印は, アンサンブル平均流速分布を示寸 $\left(<u>/ U_{0}\right)$. 流れの条件は, 図 7 と同一であ る $\left(\operatorname{Re}=1700, \alpha=2.1, \operatorname{Re}_{\delta}=570\right)$. 乱れ強度の分布は, 複雑な気道形状に強く依存し，気管と左右気管支，また 吸気と呼気の間で著しく異なった特徵を示している.

吸気位相では (図 8$)$, まず吸気開始時 $(t / T=0)$ には気管及び左右気管支とも乱れはほとんど発生していない. 乱れは加速期 $(t / T=0.125)$, 最大流量位相 $(t / T=0.25)$ 及び減速期（t/T=0.375）で発生しており，気管にお いては右気管支側の管壁近傍, 左右気管支においては第 1 分岐の内睢近傍で $u_{\mathrm{mms}}^{\prime} / U_{0}=0.2$ 程度の乱れ強度を示寸. 乱れ強度は最大流量位相で最大值を示し, 局所的には左気管支の分岐内壁近傍で $u_{\mathrm{rms}}^{\prime} / U_{0}=0.3$ に達している. 乱れ 強度の増大している領域は，どの位相においてもほぼストークス層厚さに相当する管壁から $5 \mathrm{~mm}$ 程度の領域に 限られている. 対称単分岐管内の乱れと比較した場合 ${ }^{(16)}$ ，気管の管壁近傍及び左右気管支の分岐内側壁近傍の乱 れ強度が増大している，気管や気管支の管壁には軟骨輪からなる凹凸構造があり ${ }^{(20)}$ ，管壁近傍の乱れの発生及び 増強に影響を及ぼしていると考えられる。 


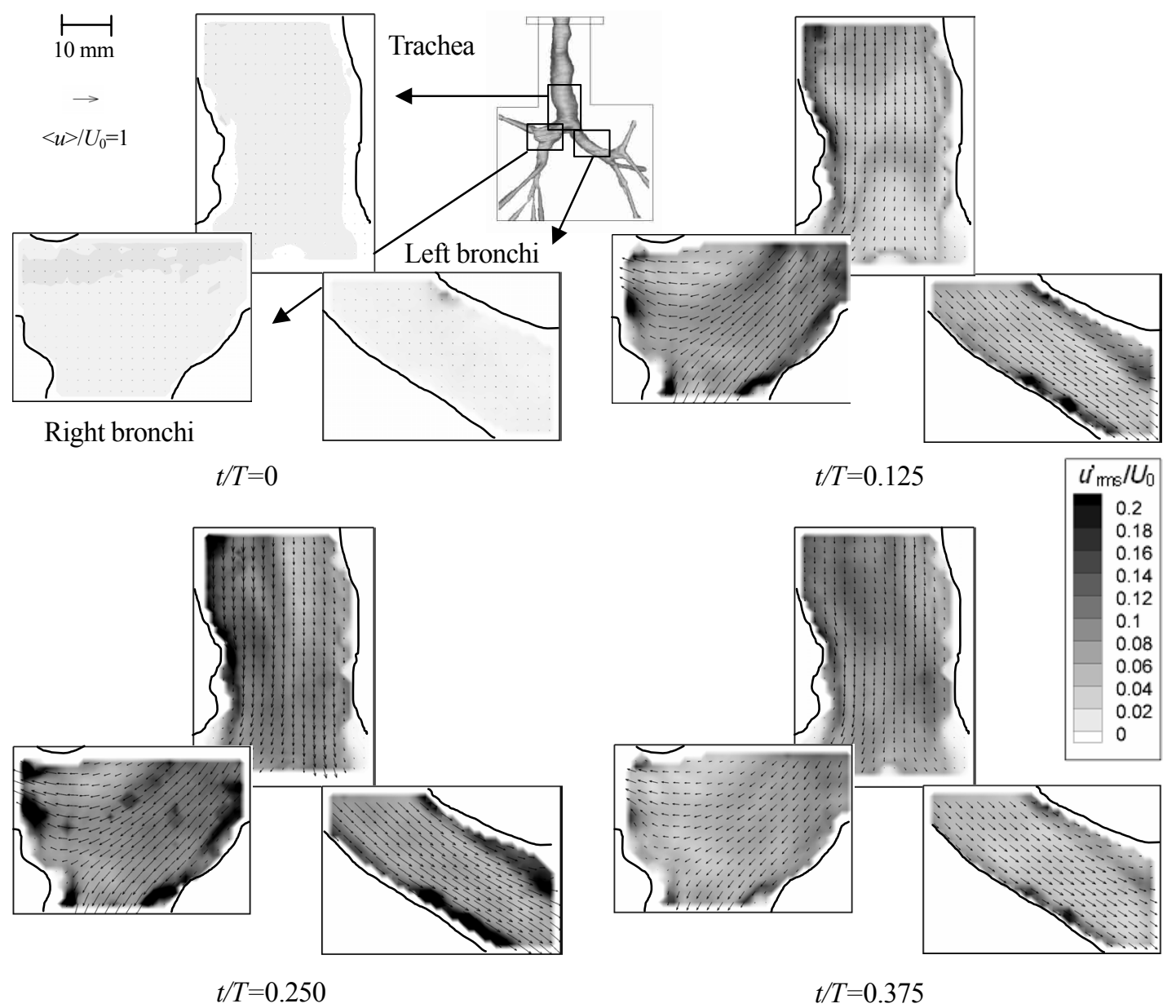

Fig. 8 Contours of turbulent intensity profile in the inspiratory phase at $\operatorname{Re}=1700$ and $\alpha=2.1$

呼気位相の乱れは（図 9), 吸気位相と比較して左右気管支で強い. 吸気と同様，呼気開始時 $(t / T=0.5)$ の乱 れは弱いが，乱れ強度は加速期（ $t / T=0.625 ）$ の特に右気管支において著しく増大し， $u_{\mathrm{rms}}^{\prime} U_{0}$ は測定断面のほぼ 全域で 0.2 以上の值を示寸. 続く最大流量位相 $(t / T=0.75)$ で乱れ強度はさらに増大し, 右気管支では右上部に 向かって分岐している気道側の合流地点で, $u_{\mathrm{rms}}^{\prime} / U_{0}$ が 0.4 を超える領域が現れている. 減速期 $(t / T=0.875)$ に おいても右気管支の上部領域の乱れは強く, $u_{\mathrm{rms}}^{\prime} / U_{0}=0.2$ 以上の值を維持している. これらの呼気位相で強い乱れ 強度を示す領域は吸気位相の場合とは著しく異なっており, 吸気位相の乱れがほぼストークス層領域に相当する 管壁近傍で発生するのに対して, 呼気位相の乱れは管壁から離れた各気道からの流れの合流地点で発生している. 対称分岐管内では, 合流により管中心軸付近が急速に加速されて鋭いピークをもつ流速分布となり，管中央付近 に形成される速度勾配のきつい領域で激しい乱れが発生することが示されている ${ }^{(16)}$. 本実験の気道モデル流路で も，呼気位相の乱れは管壁よりも分岐の合流地点で強く，気道内の乱れを特徵づけている．呼気位相の右気管支 の合流地点でみられる乱れ強度は対称分岐管内の乱れ強度より大きく, 実形状肺気道モデルでは非対称な 3 次元 的分岐形状のもとでの合流により乱れ強度が増大していると考えられる.

図 10 に，気管と左右気管支の各測定断面で算出した $u_{\mathrm{rms}}^{\prime} U_{0}$ 空間平均值の位相変化を示す．吸気位相 $(t / T=0$ ～ $0.5 ）$ では，気管，左右気管支の最大值はいずれも最大流量位相（ $t / T=0.25 ）$ でみられており，部位によらず 約 0.1 である. 加速期 $(t / T=0.125)$ と減速期（ $t / T=0.375 ）$ の乱れ強度は各部位で異なり, 気管では減速期の乱 れ強度が加速期の值より大きく, 左右気管支では加速期の乱れ強度が減速期の值より大きい特徵を示寸. 一方, 呼気位相（ $t / T=0.5 \sim 1.0 ）$ では，気管において吸気位相とほぼ同様の乱れ強度と位相変化を示すのに対し，左右 気管支においては乱れ強度が吸気よりも著しく増大し, 乱れ強度の分布には吸気と呼気の間で時間的非対称性が 生じている.また，呼気位相の乱れ強度は大きい方から右気管支，左気管支，気管の順となり，呼気位相の乱れ 強度の分布にはこれらの部位の間で著しい空間的不均一性が生じている. 


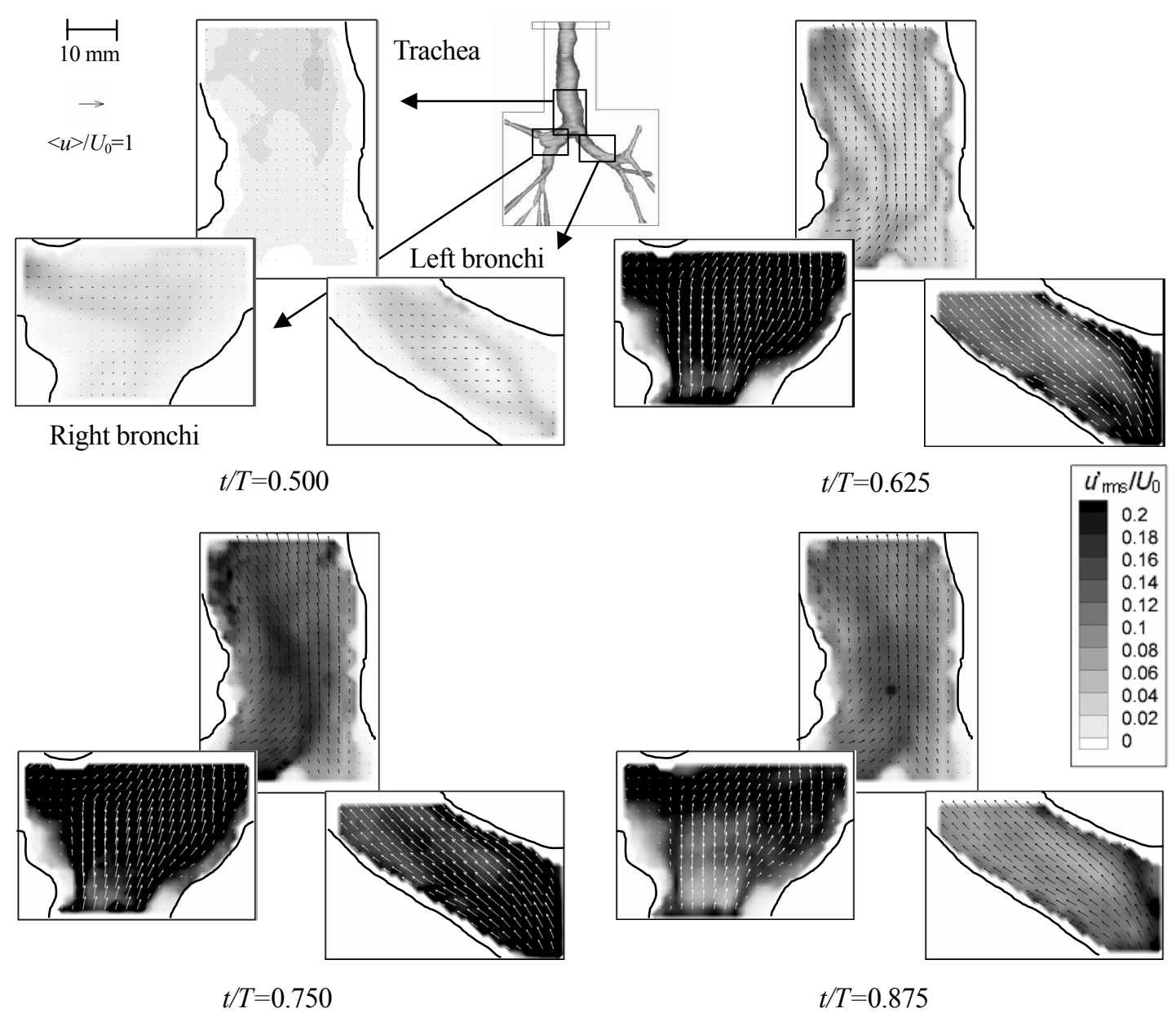

Fig. 9 Contours of turbulent intensity profile in the expiratory phase at $\operatorname{Re}=1700$ and $\alpha=2.1$

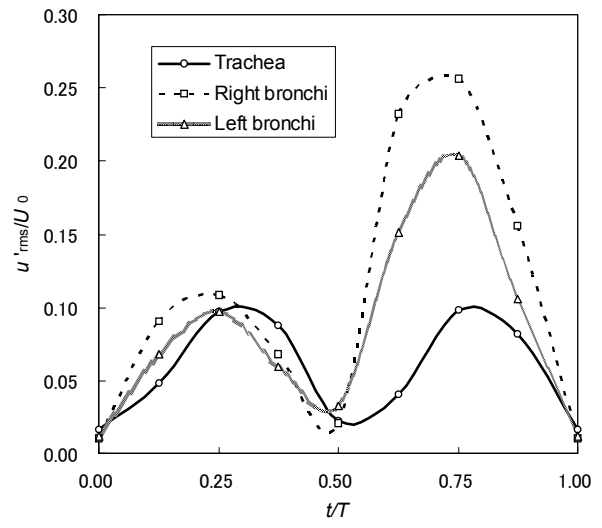

Fig. 10 Phase variation of spatial averaged turbulent intensity at $\operatorname{Re}=1700$ and $\alpha=2.1$

\section{$3 \cdot 3$ 乱れ強度に及ぼす $\operatorname{Re}$ 及び $\alpha$ の影響}

周波数を一定に保ち換気体積を増減させた場合と（ $\mathrm{Re}=1200 \sim 2200 ， \alpha=2.1)$, 換気体積を一定に保ち周波数 を増減させた場合について（Re=1400～1900， $\alpha=1.9 \sim 2.3 ）$, 気管，左右気管支の各測定断面における乱れ強度 の空間平均值の位相変化を測定した。換気体積を増加させた場合の $\operatorname{Re}_{\delta}$ は 490～590, 周波数を増加させた場合の $\operatorname{Re}_{\delta}$ は 390 710 の範囲で増加する. その結果, $\operatorname{Re}$ 及び $\alpha$ が変化しても, 乱れ強度の值及び位相変化の全体的な 傾向に大きな変化は認められず，いずれの流動条件においても右気管支の呼気位相で乱れ強度が最大となる特徵 がみられた．本実験では，直円管の場合には層流領域である低レイノルズ数条件においても，高周波の激しい乱 
れが観測されている．吸気流れにおいては壁の凹凸が，呼気流れにおいては分岐における合流が乱れの発生に強 い影響を及ぼし，比較的低いレイノルズ数から乱れが発生していると考えられる.

\section{4. 結 言}

実形状肺気道モデル流路に，安静時の呼吸条件に相当する $\mathrm{Re}=1200 \sim 2200, \alpha=1.9 \sim 2.3, \operatorname{Re}_{\delta}=390 \sim 710$ の 振動流を与え, 乱れの PIV 計測を行った. 気道モデル内には全ての条件下で激しい乱れの発生が確認され, 乱れ の空間・時間的変化について以下の知見が得られた.

1. 吸気流れでは，気管の右気管支側管壁近傍，左右気管支の分岐内壁近傍において乱れが発生する. 加速期 に発生した乱れは最大流量位相にかけて増大し，乱れ強度は局所的に $u_{\mathrm{rms}} / U_{0}=0.2$ 程度の值を示した.

2. 呼気流れでは，気管及び左右気管支の分岐合流部で吸気流れより強い乱れが発生する. 特に右気管支の乱 れ強度は最大流量位相にほぼ全域で $u_{\mathrm{rms}} U_{0}=0.25$ 以上となり, 乱れ強度の分布に著しい吸気・呼気の時間 的非対称性と気管・左右気管支間の空間的不均一性を引き起こしている.

本実験装置の設計・製作には, 当時千葉大学大学院生平野正泰君の協力を得た.

本研究の一部は, 平成 21 年度文部科学省科学研究費[若手研究(B) : 19760130]の援助を受けて行われた.

\section{文献}

（1）橋田充，1995，ドラッグデリバリーシステム，化学同人

(2) Pedley, T. J., 1977, Pulmonary fluid dynamics, Ann. Rev. Fluid Mech., vol. 9, pp. 229-274.

(3) Jan, D. L., Shapiro, A. H. and Kamm, R. D., 1989, Some features of oscillatory flow in a model bifurcation, J. Appl. Physiol., vol., 67, pp. 147-159.

（4）山口隆平, 井上猛, 渡辺耕平, 川上勝也, 1996, 対称 Y 形分岐を通る振動流の非対称性と二次流れ, 日本機械学会 論文集 B 編，vol. 62, no. 601, pp. 3250-3256.

(5) Tanaka, G., Ogata, T., Oka, K. and Tanishita, K., 1999, Spatial and temporal variation of secondary flow during oscillatory flow in model human central airways, Transactions of the ASME, J. Biomech. Eng., vol. 121, pp. 565-573.

（6）望月貞成，村田章，富樫有紀，2002，分岐管ネットワークにおける往復流による管軸方向物質輸送（ヒトの肺の誘 導気道におけるガス交換機構)，日本機械学会論文集 B 編，vol. 68, no. 667, pp. 831-838.

(7) Comer, J. K., Kleinstreuer, C. and Zhang, Z., 2001, Flow structures and particle deposition patterns in double-bifurcation airway models. Part 1. Air flow fields, J. Fluid. Mech., vol. 435, pp. 25-54.

(8) Comer, J. K., Kleinstreuer and Kim, C. S., 2001, Flow structures and particle deposition patterns in double-bifurcation airway models. Part 2. Aerosol transport and deposition, J. Fluid. Mech., vol. 435, pp. 55-80.

(9) Nowak, N., Kakade, P. P. and Annapragada, A. V., 2003, Computational fluid dynamics simulation of airflow and aerosol deposition in human lungs, Ann. Biomed. Eng., vol. 31, pp. 374-390.

(10) 稲垣原理, 田中学, 菱田誠, 羽石秀昭, 胡霄, 2007, 実形状肺気道内振動流の数值シミュレーション, 日本機械学 会論文集 B 編，vol. 73, no. 728, pp. 949-956.

(11) Miki, T., Imai, Y., Ishikawa, T. and Yamaguchi, T., 2009, Pulmonary airflow simulation of inspiration and expiration using a patient-specific model, Book of Abstracts Bioengineering 09, p. 92.

（12）鈴木慎悟, 野田茂穂, 高木周, 和田成生, 2009, 画像診断支援を目指した肺 CT ボクセルイメージに基づく気流シ ミュレーション，日本シミュレーション学会論文誌，vol. 1, no. 4, pp. 74-80.

(13) Hino, M., Sawamoto, M. and Takasu, S., 1976, Experiments on transition to turbulence in an oscillatory pipe flow, J. Fluid Mech., vol. 75, part 2, pp. 193-207.

(14) Eckmann, D. M. and Grotberg, J. B., 1991, Experiments on transition to turbulence in oscillatory pipe flow, J. Fluid Mech., vol. 222, pp. 329-350. 
(15) Akhavan, R., Kamm, R. D. and Shapiro, A. H., 1991, An investigation of transition to turbulence in bounded oscillatory flows, Part 1. Experiments, J. Fluid Mech., vol. 225, pp. 395-422.

(16) 田中学, 上田義郎, 岡庭貴志, 岡浩太郎, 谷下一夫, 2004, 分岐管気道モデル内の振動流に発生する乱れ, 日本機 械学会論文集 B 編, vol. 70, no. 696, pp. 2057-2064.

(17) 植英規, 佐藤善隆, 羽石秀昭, 外山比南子, 宮本忠昭, 山本直敬, 森豊, 2003, 胸部 X 線 CT 画像からの肺葉分割, Medical Imaging Technology, vol. 21, no. 2, pp. 122-130.

(18) Horsfield, K., Dart, G., Olson, D. E., Filley, G. F. and Cumming, G., 1971, Model of the human bronchial tree, J. Appl. Physiol., vol. 31, no. 2, pp. 207-217.

(19) Sharp, M. K., Kamm, R. D., Shapiro, A. H., Kimmel, E. and Karniadakis, G. E., J. Fluid Mech., 223 (1991), 537.

(20) Jardins, T. D., Cardiopulmonary Anatomy and Physiology. 